\title{
Influence of a Chromium-rich Industrial Waste on the Hydration and Hardening Processes of Portland Cements with Slag and Limestone Additions
}

\author{
CARMEN-LIDIA OPROIU, MARIUS-GEORGE PARVAN, GEORGETA VOICU*, \\ ALINA-IOANA BADANOIU, ROXANA TRUSCA \\ Faculty of Applied Chemistry and Materials Science, University Politehnica of Bucharest, 1-7 Gheorghe Polizu Str., \\ 011061, Bucharest, Romania
}

\begin{abstract}
This research work assesses the influence of a chromium-rich waste (from potassium dichromate manufacture) on the hydration and hardening processes of two types of Portland cements with limestone filler and slag additions. Therefore, mixtures of Portland cement and chromium-rich waste, corresponding to $0.5 \% \mathrm{wt}$. and $1 \% \mathrm{wt}$. Cr, were prepared and tested. The analyses performed on cement pastes with chromium waste content, showed that chromium immobilization is mainly due to the formation of $\mathrm{Ca}_{6} \mathrm{Al}_{2} \mathrm{Cr}_{3} \mathrm{O}_{18} \cdot 32 \mathrm{H}_{2} \mathrm{O}(\mathrm{CrEt})$; this compound results by the substitution of $\left[\mathrm{SO}_{4}\right]^{2-}$ groups from ettringite lattice of with $\left[\mathrm{CrO}_{4}\right]^{2-}$. CrEt crystals growth on the surface of clinker particles forms a diffusion barrier which explains longer setting times for cements with chromium content. The increase of chromium content in the studied systems decreases the compressive strength values but these remain above the lower limits imposed for this type of materials. The chromium content in leachates prepared according to the method described in SR EN 12457-2, was well below the legal limit of $70 \mathrm{mg} / \mathrm{Kg}$ established by Romanian legislation. A better chromium immobilisation was achieved in the cement with slag content, in good correlation with the nature and amount of formed hydrates.
\end{abstract}

Keywords: Chromium rich industrial waste; Hydraulic binders; Hardening and immobilisation processes.

In cement industry various types of waste can be recycled as secondary materials with positive impact on the environment protection as well as on the energy consumption [1-6].

Toxic waste can be immobilised in hardened cement stone by solidification/stabilization. (S/S) [1, 6, 15, 7-14]. Solidification describes the processes that transform waste into a waterproof solid with strong cohesion and with good physical and mechanical properties. Stabilization is the effect of processes aiming to reduce or even eliminate the mass transfer phenomena of pollutants into water and soil. S/S technique involves the mixing of waste with a binder (organic or inorganic) allowing to final product to meet the standards imposed by environmental legislation.

Solidification/stabilization of toxic elements (e.g. $\mathrm{Zn}, \mathrm{Pb}, \mathrm{Co}, \mathrm{Cu}, \mathrm{Cr} \mathrm{Cd}, \mathrm{Mn}$ ) in various types of cementations matrices (lime, cement, geopolymers etc) were assessed by leaching tests [9, 11, 20, 21, 12-19].

One of the toxic elements commonly encountered in waste from metallurgic industry is chromium. This element can be trivalent $\left(\mathrm{Cr}^{3+}\right)$ or hexavalent $\left(\mathrm{Cr}^{6+}\right)$, the last one being considered very toxic [18]. Several studies of the last decade pointed out the possibility to efficiently immobilize this element in hardened Portland cement by physical and chemical processes [17-21].

In a previous study, our research group used to immobilize the chromium from an industrial waste two specially designed Portland composite cements with a low sulphate content [21]. These binding matrices proved to be less efficient in the immobilisation of this toxic element, due to the high $\mathrm{pH}$ developed during the hardening processes, which contributed to the increase of chromium solubility [22].

Based on these results, correlated with literature date which suggest an efficient immobilization of $\mathrm{Cr}$ in an ettringite-like phase formed during Portland cement hydration [18], in present paper it was studied the efficiency of immobilization of a chromium-rich waste in composite Portland cements, with slag and limestone content. The influence of chromium on the hydration and hardening processes of studied cements was also assessed.

\section{Experimental part}

Materials and methods

The materials used for this study were:

i) two types of Portland cements:

- CEM II / A-M (S-LL) - with the following components: clinker (76.6\%); limestone (9.9\%); blast furnace slag (5.1\%); siliceous addition (2.6\%); setting regulator (5.9\%);

\footnotetext{
*email:gerogeta.voicu@upb.ro
}

- CEM II / A-L (LL) - with the following components: clinker (86.9\%); limestone (5.7\%); siliceous addition $(2.5 \%)$; setting regulator $(4.9 \%)$. 
The oxide composition and the Blaine specific surface area of these cements are presented in Table 1 .

ii) a chromium-rich waste resulted in the potassium dichromate manufacture. The main characteristics of this waste were reported in a previous study [21]. The main crystalline phases assessed by XRD in the chromium waste were: calcium chromium oxide hydrate (PDF 37-1367), calcium hydroxide (PDF 84-1270), calcium carbonate (PDF 050586) and magnesium hydroxide (PDF 44-1482) [21]. The chromium concentration in the resulted powder was 2.71 wt\%, much higher than any another heavy elements assessed in this waste (Ni, Ti, V, W, Zn etc.) [21].

Before mixing with the cements, the chromium waste was dried at $50^{\circ} \mathrm{C}$ for $48 \mathrm{~h}$ and homogenized in a planetary ball mill for 30 minutes.

The main characteristics of cements, with/without chromium-rich waste addition, are given in Table 2. Chromium waste was dosed to yield 0.5 and 1 wt. \% chromium content in cement.

Table 1

OXIDE COMPOSITION (wt. \%) AND BLAINE SPECIFIC SURFACE AREA $\left(\mathrm{cm}^{2} / \mathrm{g}\right)$ OF CEMENTS

\begin{tabular}{|c|c|c|c|c|c|c|c|c|}
\hline & $\mathbf{S i O}_{2}$ & $\mathbf{A l}_{2} \mathbf{O}_{3}$ & $\mathbf{F e}_{2} \mathbf{O}_{3}$ & $\mathbf{C a O}$ & $\mathbf{M g O}$ & $\mathbf{S O}_{3}$ & PC & $\mathbf{S}_{\text {sp. }}$ \\
\hline $\begin{array}{c}\text { CEM II/A-M(S-LL) } \\
\text { Symbol: L }\end{array}$ & 18.40 & 5.09 & 3.79 & 61.30 & 1.39 & 3.69 & 5.75 & 3754 \\
\hline $\begin{array}{c}\text { CEM II/A-L (LL) } \\
\text { Symbol: C }\end{array}$ & 19.50 & 4.01 & 4.38 & 63.11 & 0.76 & 3.09 & 4.04 & 2754 \\
\hline
\end{tabular}

Table 2

COMPOSITIONS AND PROPERTIES OF THE STUDIED CEMENTS (WITH/WITHOUT CHROMIUM WASTE CONTENT)

\begin{tabular}{|c|c|c|c|c|c|}
\hline $\begin{array}{c}\text { Symbol } \\
\text { binder }\end{array}$ & $\begin{array}{c}\mathbf{C} \\
(\mathbf{w t . \%})\end{array}$ & $\begin{array}{c}\mathbf{L} \\
(\mathbf{w t . \%})\end{array}$ & $\begin{array}{c}\text { Waste } \\
(\mathbf{w t . \%})\end{array}$ & $\begin{array}{c}\text { Density } \\
\left(\mathbf{g} / \mathbf{c m}^{\mathbf{3}}\right)\end{array}$ & $\begin{array}{c}\mathbf{S}_{\mathbf{s p}}{ }^{*} \\
\left(\mathbf{c m}^{\mathbf{2}} \mathbf{/ g}\right)\end{array}$ \\
\hline $\mathbf{C 0}$ & 100 & - & - & 3.184 & 2755 \\
\hline C05 & 81.55 & - & 18.45 & 3.077 & 3303 \\
\hline $\mathbf{C 1}$ & 63.1 & - & 36.9 & 2.886 & 3836 \\
\hline L0 & - & 100 & - & 3.149 & 3754 \\
\hline L05 & - & 81.55 & 18.45 & 3.026 & 4235 \\
\hline L1 & - & 63.1 & 36.9 & 2.884 & 4622 \\
\hline \multicolumn{7}{|c}{ * Blaine specific surface area } \\
\hline
\end{tabular}

For the assessment of phase composition of studied materials, X-ray diffraction (XRD) and infrared spectroscopy (FT-IR) were performed. The XRD analyses were carried with Schimadzu diffractometer XRD 6000 (with Ni-filtered $\mathrm{CuK} \alpha(\lambda=1.5406 \dot{\mathrm{A}})$ radiation, scanning speed of $2 \mathrm{deg} . / \mathrm{min}$. in 2 theta range of 5 -65 degree). The FT-IR analyses were performed using a Thermo Scientific Nicolet ${ }^{\mathrm{TM}}$ iS $^{\mathrm{TM}} 50$ spectrometer, equipped with an ATR module based on diamond crystal; the spectra were recorded over the wavenumber range of $150-2000 \mathrm{~cm}^{-1}$ with a resolution of $2 \mathrm{~cm}^{-1}$.

The microstructure of the studied materials was assessed using a Quanta Inspect F scanning electron microscope (1.2 $\mathrm{nm}$ resolution; SEM) with EDX, and the samples were coated with a gold thin layer.

The density of the cements (with/without $\mathrm{Cr}$ waste content) was measured by Arhimede's method using a helium pycnometer. The fineness was assessed with a Blaine Permeability Surface Area Analyzer according to SR EN 196-6, Part 6 [23].

The hydration and hardening processes of studied cements (with/without chromium waste content) were assessed on pastes with water to binder ratio of 0.5 , hardened in sealed containers for 2 up to 90 days. The water for normal consistency and setting time of studied cements were determined according to SR EN 196-1, Part 3. [24].

Compressive strengths were assessed on mortar specimens prepared with a dosage corresponding to cement: sand $=$ 1:3 and water to binder ratio of 0.5; the aggregate was siliceous sand as specified in SR EN 196-1, Part 1 [25]. The mortar specimens were cast in rectangular molds $(15 \times 15 \times 60 \mathrm{~mm})$, vibrated for 2 minutes and cured for 7 up to 180 days in humid air (R.H. 90\%). The compressive strength was assessed using a Matest machine and the final values represent the average of four strength values assessed on specimens cured in similar conditions.

Chromium immobilization in the studied cements was estimated considering the chromium concentration of a leachate formed after the immersion, for 24 hours, in distilled water of the granular material resulted by the crushing of cement pastes hardened for 28 days; the samples preparation was made in accordance with the method presented in SR EN 12457-2 [26]; the chromium concentration in leachate was determined by inductively coupled plasma - optical emission (ICP-OES) technique with a transcribed apparatus conductively coupled plasma optical emission spectrometer.

\section{Results and discussions}

The XRD analyses of cements $\mathrm{L}$ and $\mathrm{C}$ (Fig. 1) shows the presence of: tricalcium silicate $\left(\mathrm{C}_{3} \mathrm{~S}\right.$; PDF 42-0551), dicalcium silicate $\left(\mathrm{C}_{2} \mathrm{~S}\right.$; PDF 33-0303), tetracalcium aluminoferrite $\left(\mathrm{C}_{4} \mathrm{AF}\right.$; PDF 11-0124), tricalcium aluminate $\left(\mathrm{C}_{3} \mathrm{~A}\right.$; 
PDF 33-0251) and gypsum ( $\mathrm{C} \overline{\mathrm{S}} \mathrm{H}_{2}$; PDF 33-0311). One can notice that XRD patterns of cements $\mathrm{L}$ and $\mathrm{C}$ do not have major differences from compositional point of view; nevertheless, based on the intensities of XRD peaks one can assume that the crystals present in cement $\mathrm{L}$ are smaller compared with those present in cement $\mathrm{C}$.

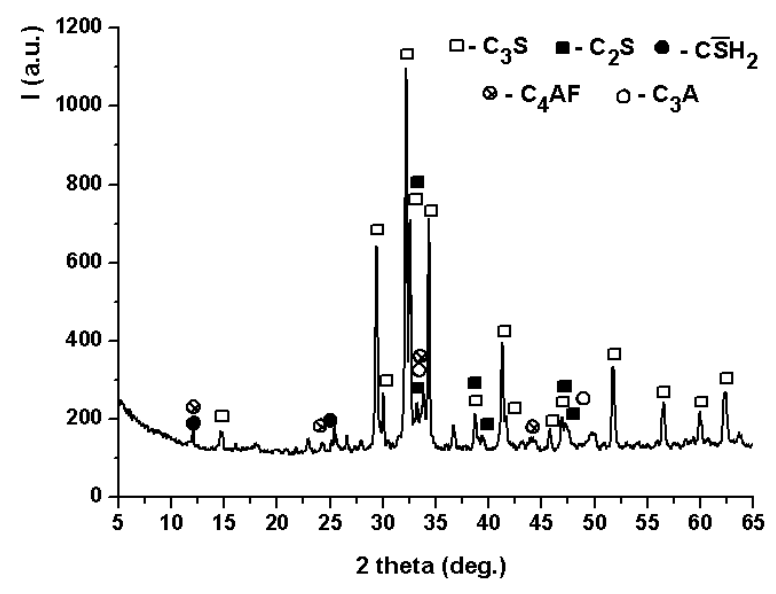

a

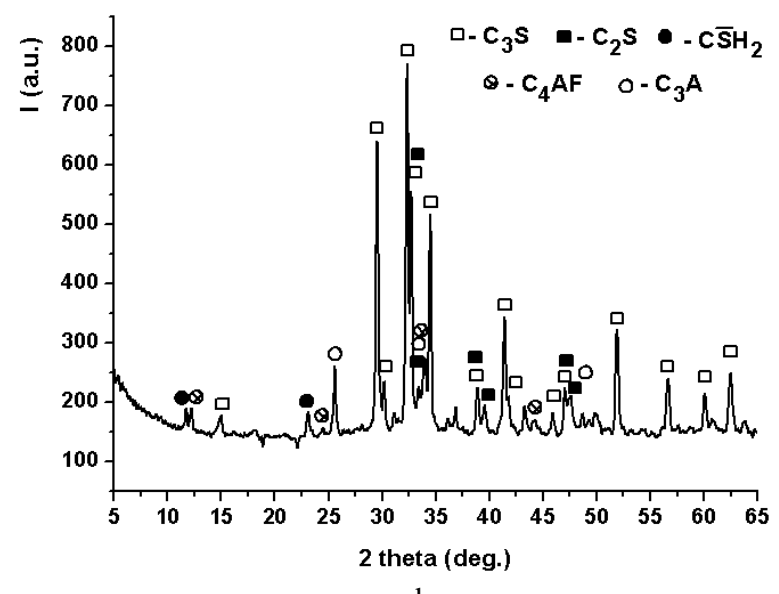

b

Fig. 1 XRD patterns of anhydrous cements: $a-C ; b-L$

Fig. 2 shows the FT-IR spectra of chromium waste and anhydrous cements (C and L) with $0.5 \%$ and $1 \% \mathrm{Cr}$ content. According to literature data $[18,19,27-29]$ the absorption bands on the FT-IR spectra, can be attributed to:

- for chromium-rich waste, at $1414 \mathrm{~cm}^{-1}$ and $870 \mathrm{~cm}^{-1}$ the absorption bands are attributed to the $\mathrm{CO}_{3}{ }^{2-}$ bonds from $\mathrm{Ca}(\mathrm{Mg}) \mathrm{CO}_{3}$; the band from $870 \mathrm{~cm}^{-1}$ is attributed of the $\mathrm{CrO}_{4}{ }^{2-}$ bonds from the $\mathrm{CaCrO}_{4} \cdot 2 \mathrm{H}_{2} \mathrm{O}$; at about $716 \mathrm{~cm}^{-1}$ the shoulder can be correlated with the presence of $\mathrm{SiO}_{2}$ in waste;

- for anhydrous cements (with/without chromium waste content), one can assess a board absorption band at 1429 $\mathrm{cm}^{-1}$ associated with the presence of the carbonate group; the band from $596 \mathrm{~cm}^{-1}$ is specific to $\mathrm{SO}_{4}{ }^{2-}$ group from gypsum; the bands from $712 \mathrm{~cm}^{-1}$ and $920 \mathrm{~cm}^{-1}$ are associated to presence of $\mathrm{C}_{3} \mathrm{~A}$ and the shoulder from $1092 \mathrm{~cm}^{-1}$ is attributed to $\mathrm{C}_{4} \mathrm{AF}$. The bands from $450 \mathrm{~cm}^{-1}$ and $516 \mathrm{~cm}^{-1}$, are attributed to the vibration of the $\mathrm{O}-\mathrm{Si}-\mathrm{O}$ bonds, from calcium silicates.

The values of water for normal consistency and setting time of cement pastes are presented in Figure 3. The increase of chromium waste content determines an increase of the amount of water for normal consistency for both cements (Fig. 3a); this increase can be correlated with the increase of cements fineness (see values of Blaine specific surface area Ssp - see table 2).

The values of setting time (Fig. 3b) depends significantly on the amount of chromium waste, the characteristics of cements (composition, fineness) and the amount of water for normal consistency. The increase of chromium waste dosage determines a delay of cement hydration (both initial and final setting times increases), in correlation with the kinetic of cement hydration processes and formed hydrates, as will be explained further.

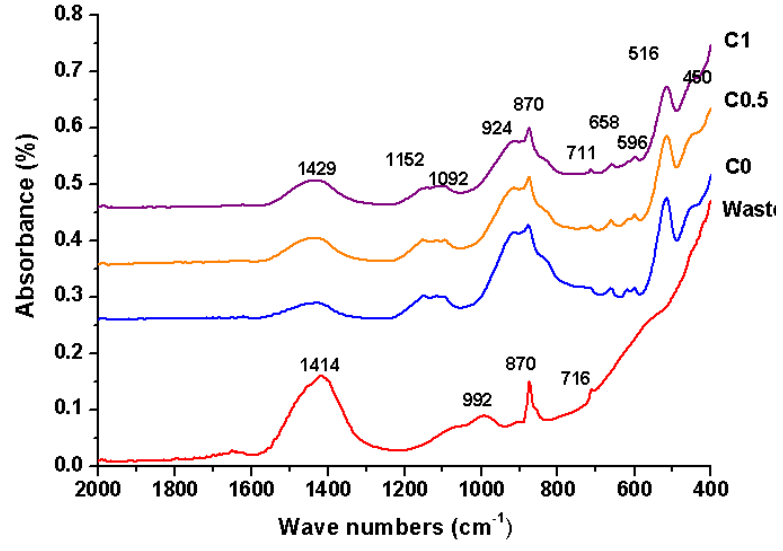

a

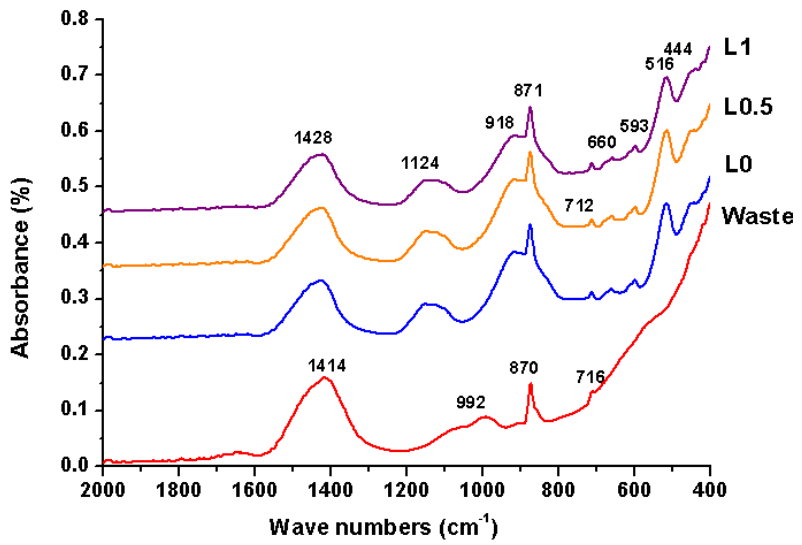

b

Fig. 2. The FT-IR spectrum characteristic of waste with high chromium content and the anhydrous cements 

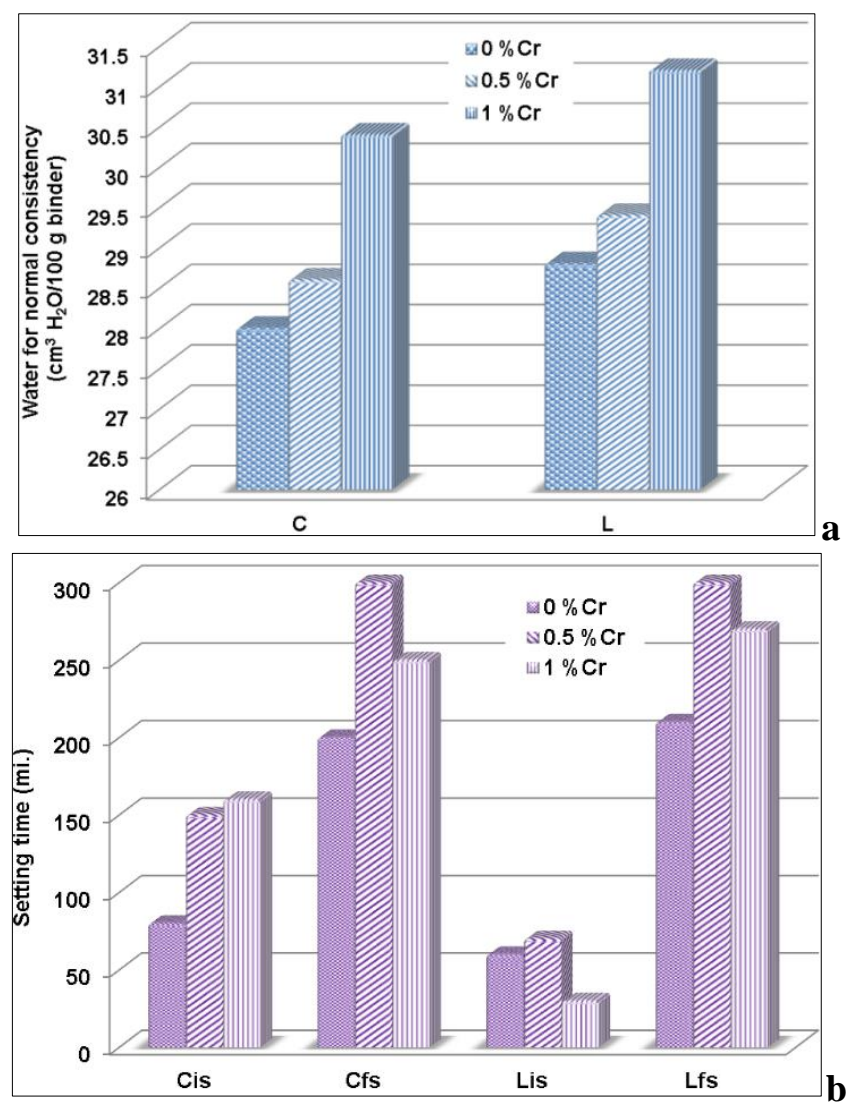

Fig. 3 Water for normal consistency (a) and setting time

(is-initial; fs-final) (b) assessed on cements without/with chromium-rich waste content

The compressive strengths of cement mortars with various amounts of chromium waste are presented in Fig. 4. For all studied cements, the compressive strengths increase with the increase of curing time, from 7 days up to 180 days. The increase of waste dosage determines a decrease of compressive strengths. This effect can be due to: i) the occurrence of new hydrates with chromium content (in large quantities) and ii) a "dilution effect" of cement when chromium waste is used to substitute it in various amounts $-18.4 \%$ (for $0.5 \% \mathrm{Cr}$ ) or $36.9 \%$ (for $1 \% \mathrm{Cr}$ ).

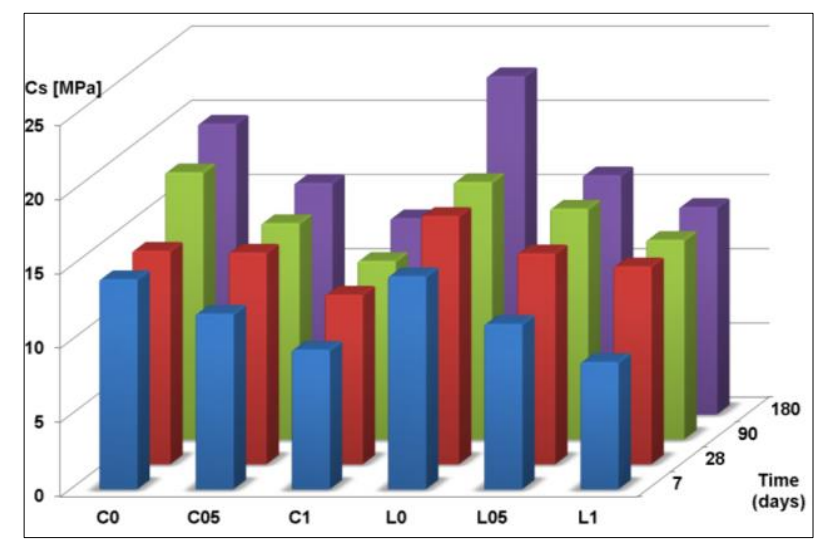

Fig. 4.Compresive strength (Cs) of binders without / with Chromium waste content vs, hardening time

XRD patterns of cement pastes hardened for 2 up to 90 days (Fig. 5 and 6) shows the decrease of the intensities of XRD peaks specific for anhydrous compounds (see also Fig.1); it can be also noticed the occurrence of XRD peaks specific for crystalline hydrates formed by cement hydration: calcium hydroxide (CH; PDF 72-0156), ettringite (AFt; PDF 72-0646), calcium silicates hydrates (CSH; PDF 72-0156; low intensity). The presence of calcium carbonate $(\mathrm{C} \overline{\mathrm{C}}$; PDF 24-0027) in hydrated cements without waste content $(\mathrm{C}$ and $\mathrm{L})$ is explained by the partial carbonation with atmospheric $\mathrm{CO}_{2}$. Also, for the cement pastes with waste, the calcium carbonate is present and as a consequence of its presence in waste.

On the XRD patterns of cements with waste content $(\mathrm{C} 0.5, \mathrm{C} 1, \mathrm{~L} 0.5$ and L1) can be also detected the presence of a hydrate with chromium content - $\mathrm{CrO}_{4}$-ettringite (CrEt; PDF 41-0218). According to Zhang et all. [18, 19] in this ettringite-like phase, $\left[\mathrm{SO}_{4}\right]^{2-}$ groups are replaced by $\left[\mathrm{CrO}_{4}\right]^{2-}$. A confirmation of the presence of this compound in the 
cement pastes with waste content is the shifting of XRD peaks at smaller angles $(2 \theta)$ - see inserts in fig. 5 b,c and 6 b,c. According to literature data [18] CrEt growths on the surface of clinker particles and forms a diffusion barrier which explains the longer setting times assessed for the cements with chromium content (see Fig. 3b).

The discontinuous variation vs. time of the intensity of XRD peals specific for ettringite (see fig. 5a and 6a) could be due to its partial transformation in calcium aluminate monosulfate (AFm) [30, 31]; its presence cannot be assessed on XRD patterns due to its small quantities and low crystallinity.

FT-IR spectra (Figs. 7 and 8) can provide additional information on the kinetic of cement hydration and the mechanism of chromium immobilization. The formation of ettringite during cement hydration is assessed by the presence of specific absorption bands in the range $1105-1115 \mathrm{~cm}^{-1}[27,28]$, present on FT-IR spectra of all cement pastes (hydrated for 2 up to 90 days).

The absorption band from $1675 \mathrm{~cm}^{-1}$ is attributed to molecular water and the band from $1415 \mathrm{~cm}^{-1}$ is attributed to the vibration of $\mathrm{CO}_{3}{ }^{2-}$ bond. The presence of $\left[\mathrm{CrO}_{4}\right]^{2-}$ in cement pastes with waste content is confirmed by the band from $873 \mathrm{~cm}^{-1}$ [29].

It is important to mention that for the hydrated samples the $\mathrm{Si}-\mathrm{O}$ band is the shifting from approximately $924 \mathrm{~cm}^{-1}$ (specific for anhydrous calcium silicates) to $953-963 \mathrm{~cm}^{-1}$ (specific for calcium silicate hydrates). This change in the position of the absorption band can be attributed to the polymerization of $\left[\mathrm{SiO}_{4}\right]^{4-}$ units of from $\mathrm{C}_{3} \mathrm{~S}$ and $\mathrm{C}_{2} \mathrm{~S}$ in the presence of water as a result of the formation of calcium silicates hydrates [27].

The microstructure of mortars hardened 7 and 28 days was assessed by scanning electron microscopy - SEM (Figs. 9 and 10).

One can observe the presence of calcium silicates hydrates $(\mathrm{CSH})$ with specific shapes - foils or thin needles, calcium hydroxide $(\mathrm{CH})$ as hexagonal plates and ettringite $(\mathrm{AFt})$ crystals with the characteristic shape of needle-like hexagonal prisms [19, 30-32].

In presence of chromium rich waste, the hexagonal platelets specific for Cr-Et (aprox. $1 \mu \mathrm{m}$ ) [19] can be also noticed (Figs. 9 and 10). The hexagonal platelets are much more visible in the cements with a higher chromium content (L1 and C1).
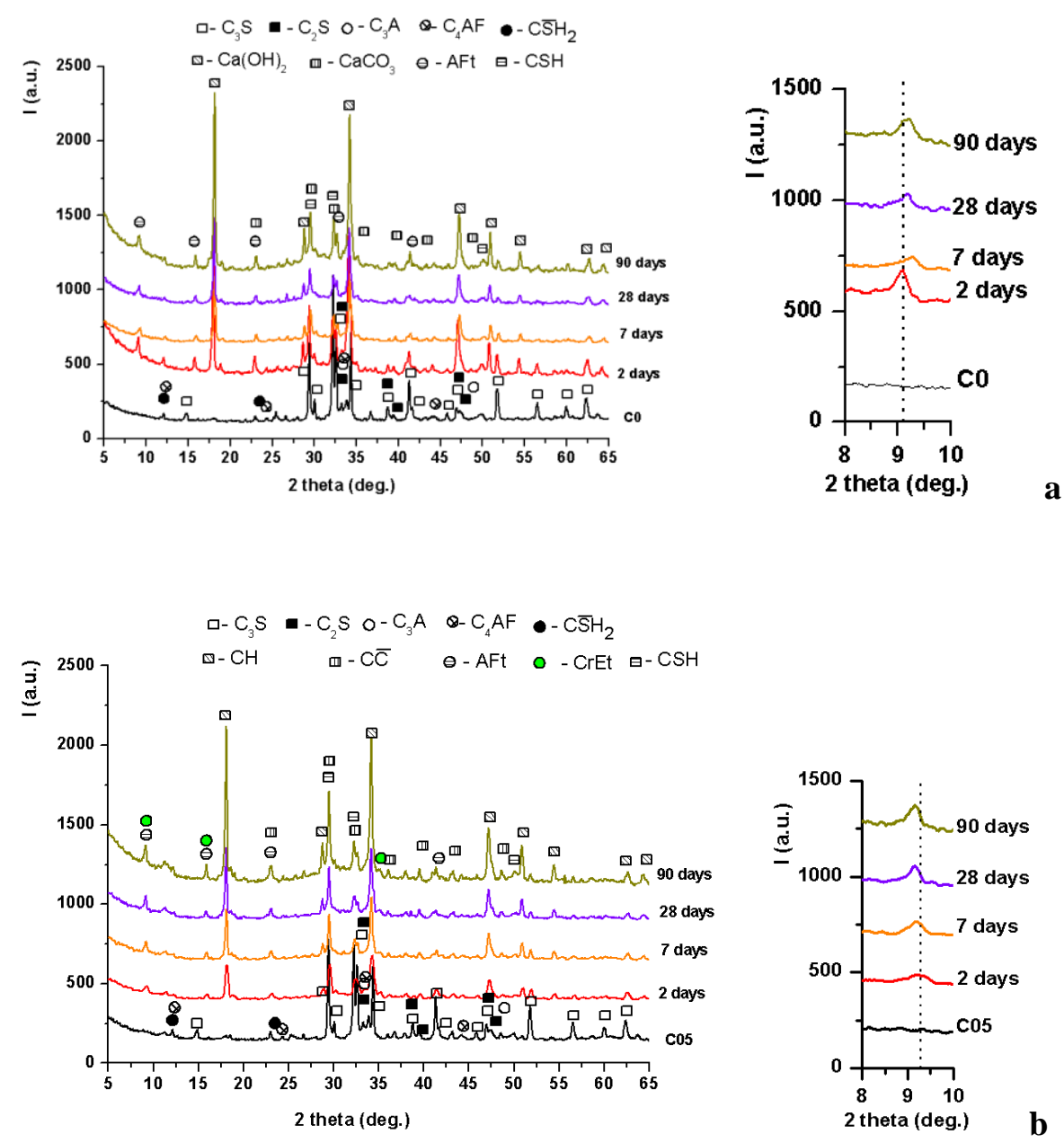

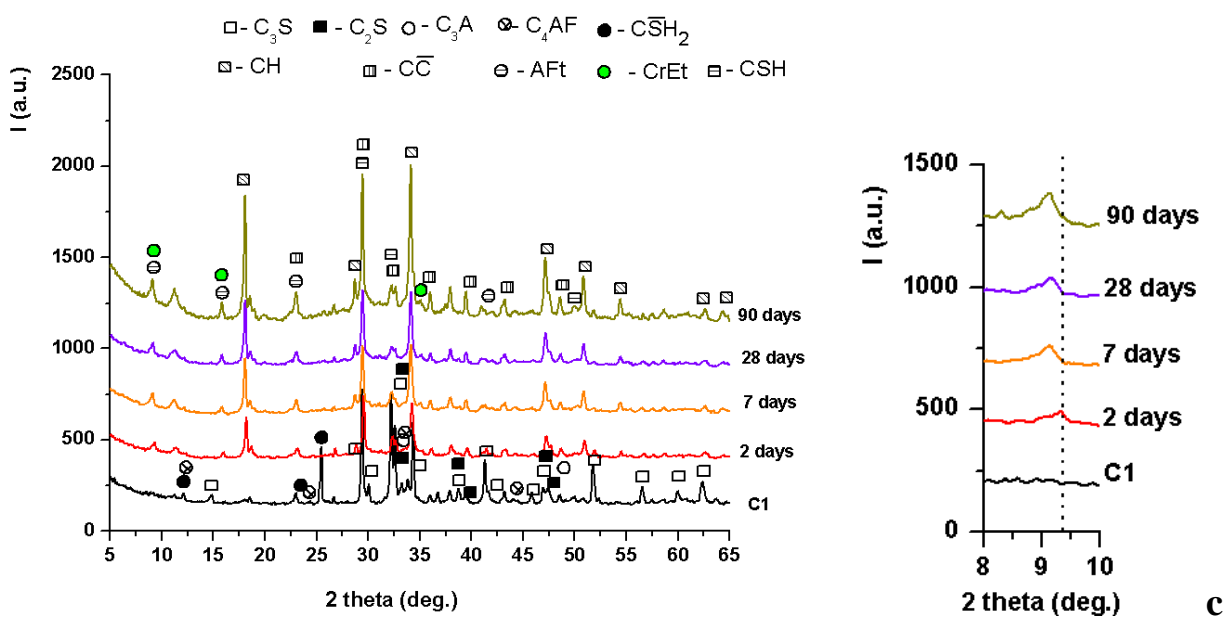

Fig. 5 XRD patterns of cement $\mathrm{C}$ (with/without chromium waste) anhydrous and hydrated for 2, 7, 28 and 90 days: a- C0; b- C05; c- C1
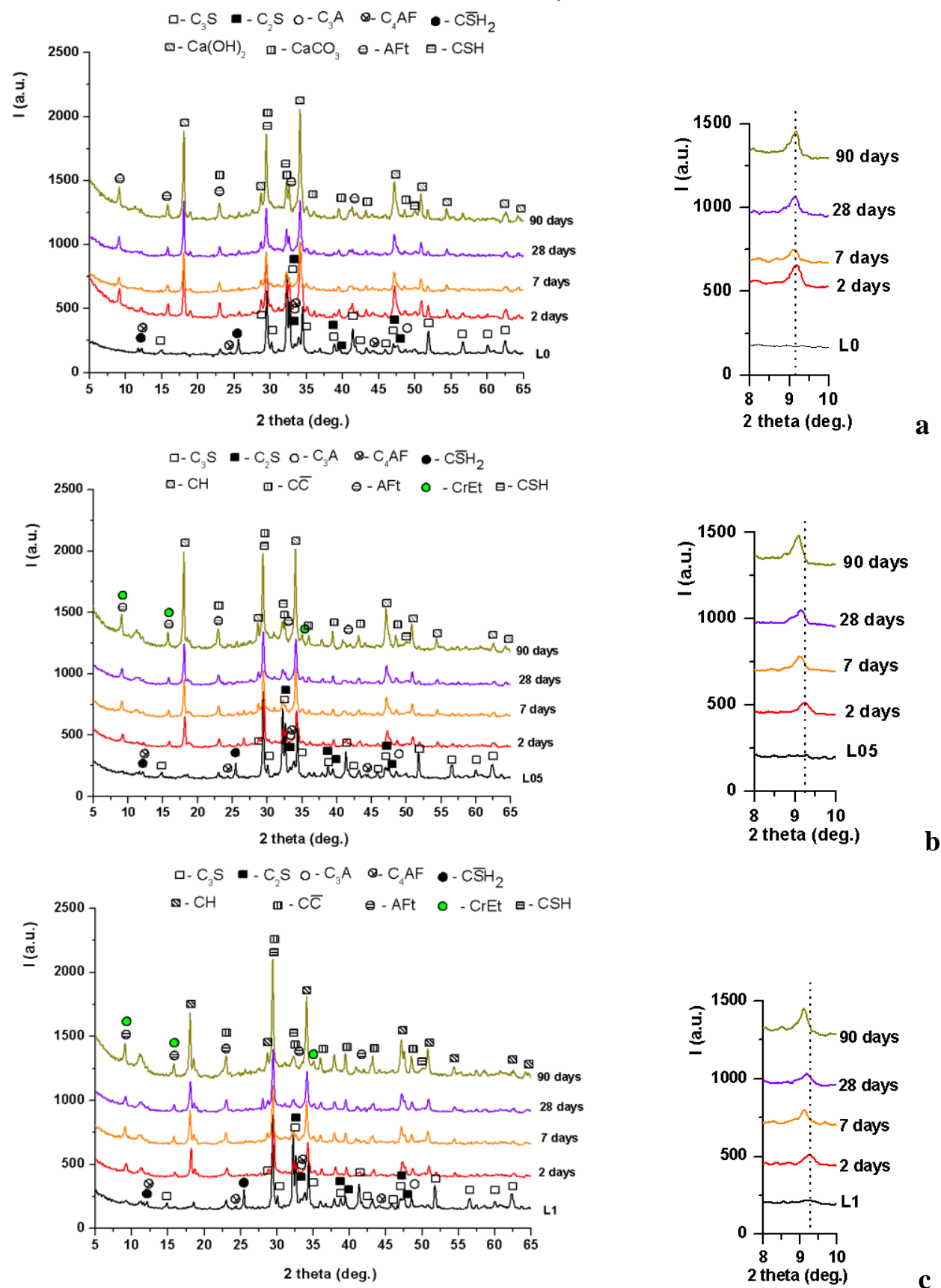

Fig. 6 XRD patterns of cement L (with/without chromium waste) anhydrous and hydrated for 2, 7, 28 and 90 days: a- L0; b- L05; c- L1 

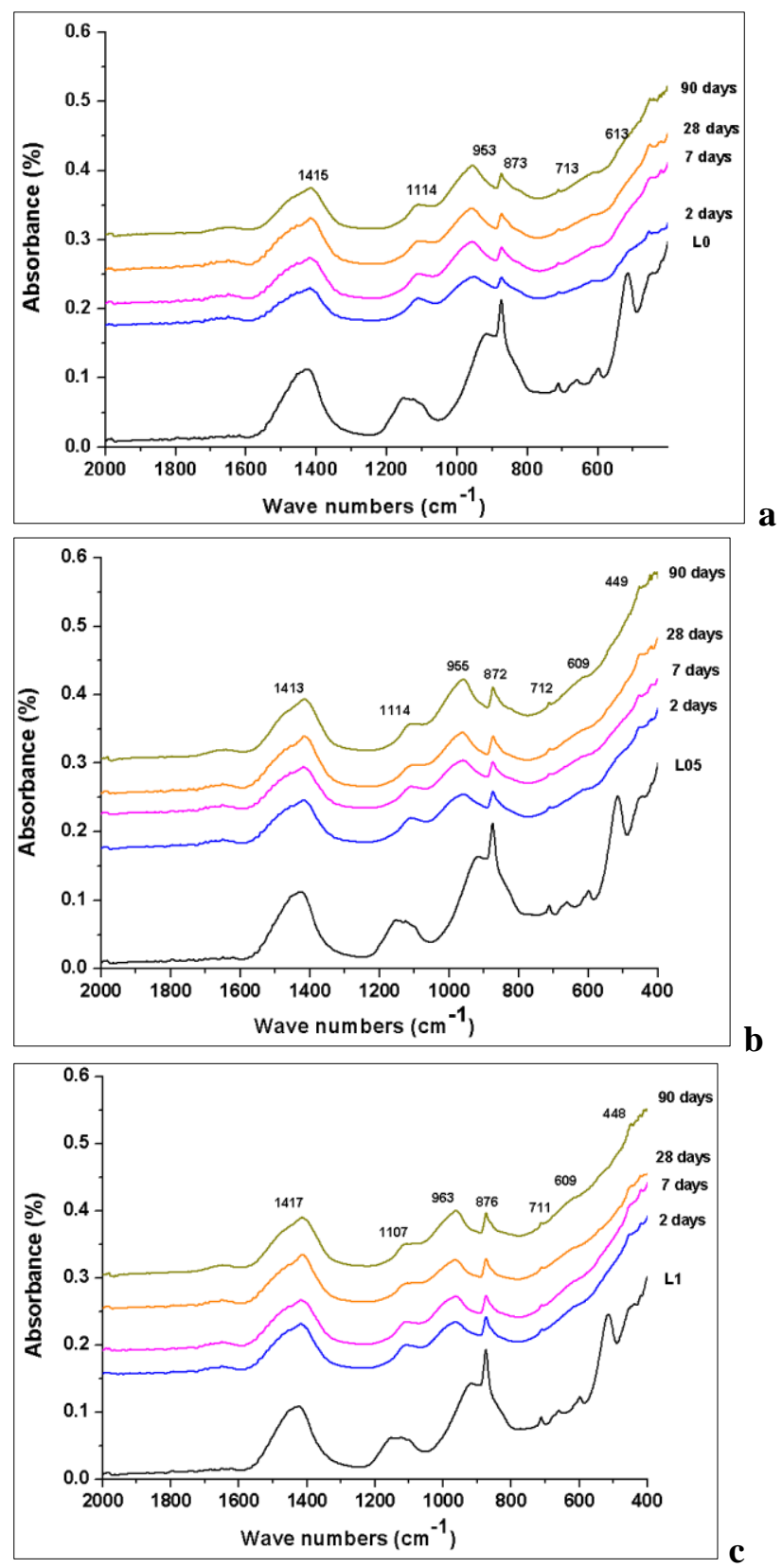

Fig. 7 FT-IR spectra of cements L with different chromium waste content, anhydrous or hydrated for $2-90$ days: a) $0 \% \mathrm{Cr}$; b) $0.5 \% \mathrm{Cr}$; c) $1 \% \mathrm{Cr}$

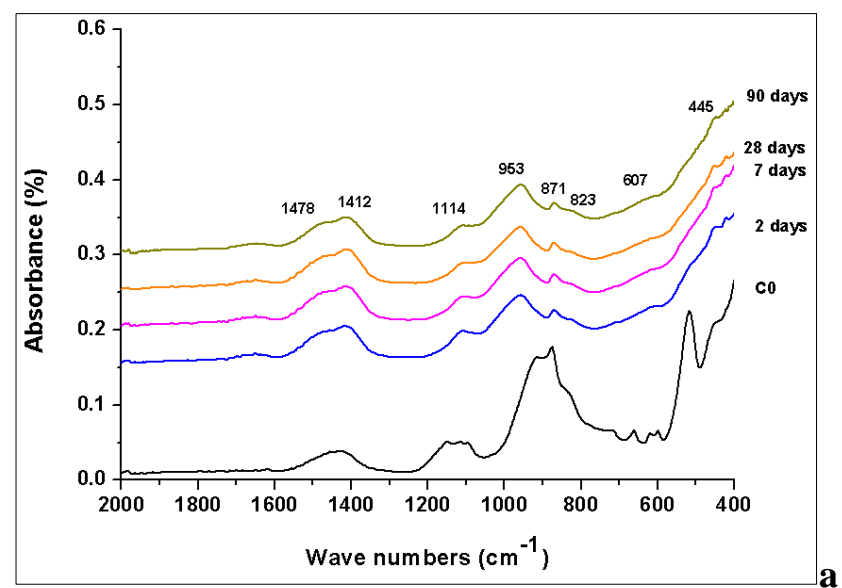



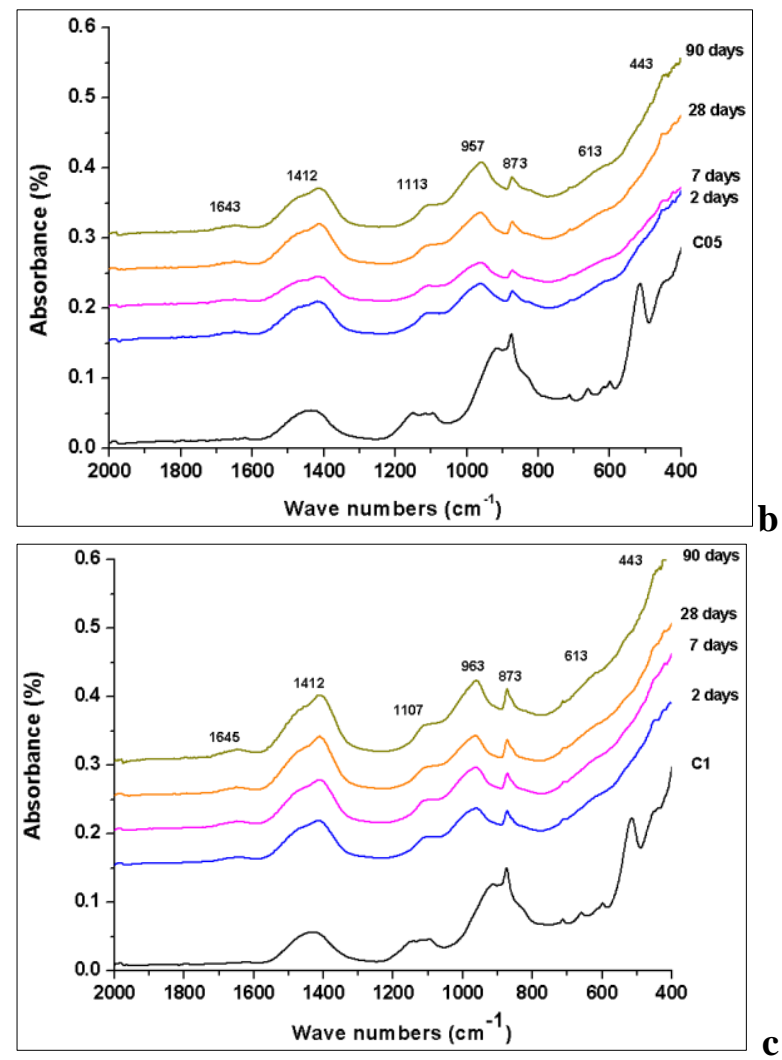

Fig. 8 FT-IR spectra of cements $\mathrm{C}$ with different chromium waste content, anhydrous or hydrated for $2-90$ days: a) $0 \% \mathrm{Cr}$; b) $0.5 \% \mathrm{Cr}$; c) $1 \% \mathrm{Cr}$
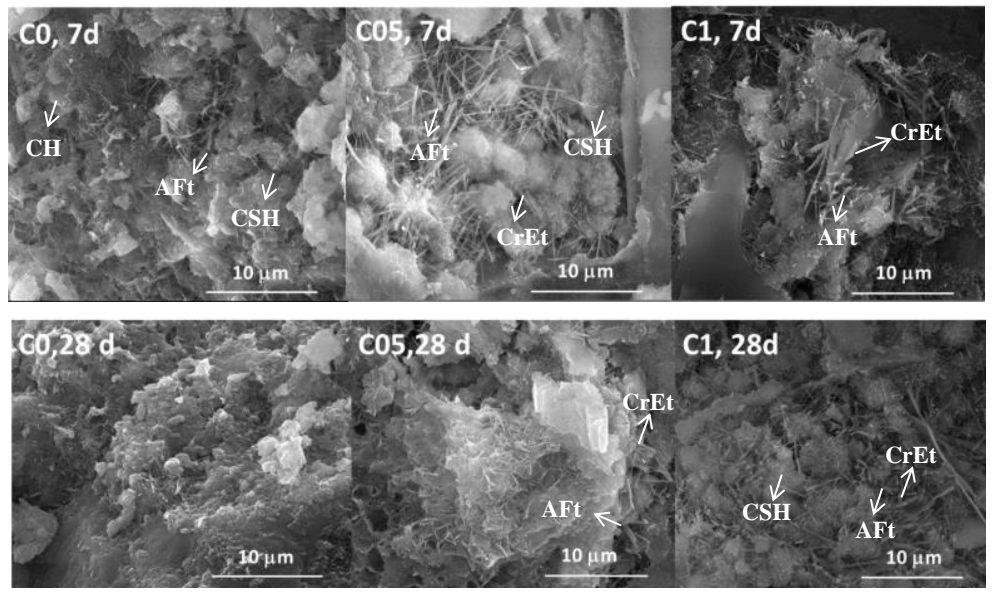

Fig. 9. SEM images for C-type mortars with / without chromium waste, hydrated 7 days (7d) and 28 days (28d)
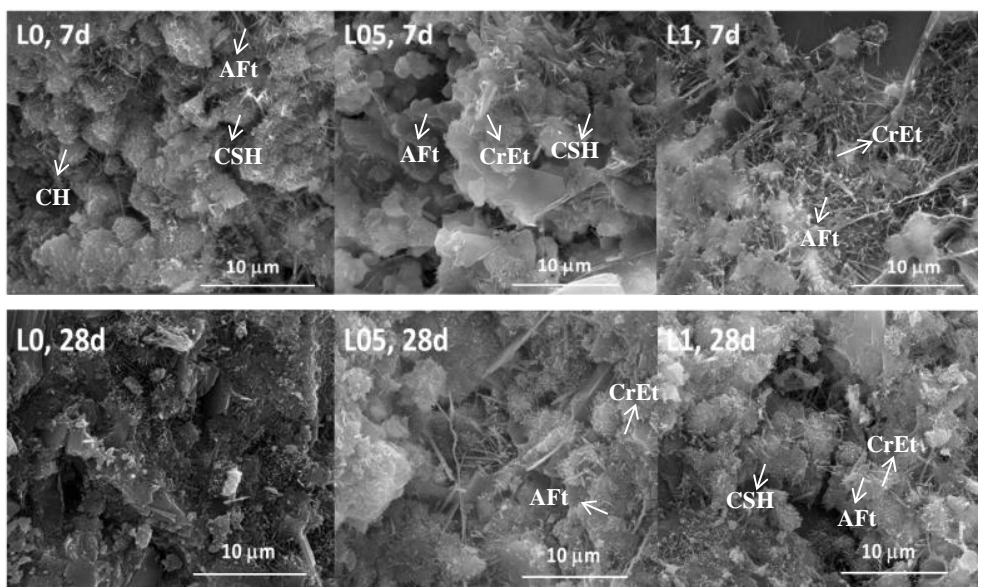

Fig. 10 SEM images for L-type mortars with / without chromium waste hydrated 7 days $(7 \mathrm{~d})$ and 28 days $(28 \mathrm{~d})$ 
Information about the capacity of studied cements to immobilize chromium, is provided by the ICP-OES data (Table 3). One can notice that all the values of chromium concentration in the leachates are below the limit stipulated in specific regulation i.e. $70 \mathrm{mg} / \mathrm{Kg}[26,33]$.

The immobilization of $\mathrm{Cr}$ is more efficient in $\mathrm{L}$ cement as compared with $\mathrm{C}$ cement, most probably due to slag content and consequently due to a higher amount of calcium silicate hydrates in the hardened paste, chromium being immobilised in these hydrates [19].

Table 3

CONCENTRATION OF CHROMIUM IN LEACHATES PREPARED

\begin{tabular}{|c|c|c|c|c|c|c|}
\hline \multicolumn{7}{|c|}{ ACCORDING TO SE EN 12457-2 } \\
\hline Symbol binder & L0* & L05 & L1 & C0 $*$ & C05 & C1 \\
\hline$[\mathbf{C r}](\mathbf{p p m})$ & 0.0127 & 5.5060 & 13.0030 & 0.1223 & 7.4350 & 14.2030 \\
\hline
\end{tabular}

The chromium immobilization in these binding matrices is more efficient as compared with those used in the previous study [21]; this is due, to the lower $\mathrm{pH}$ of these binding systems (due to slag content) as well as to the high sulphate content which favours the formation of ettringite with chromium content (CrEt).

\section{Conclusions}

A good immobilization of chromium (from an industrial waste) was achieved in binding matrices based on two type of cements: i) CEM II / A-M (S-LL) with slag and limestone addition and ii) CEM II / A-L (LL) with limestone filler.

The results obtained in this study, correlated with literature data, suggest the immobilization of chromium via absorption on the gel-like calcium silicate hydrates and occurrence of a new hydrate ettringite like phase $\mathrm{Ca}_{6} \mathrm{Al}_{2} \mathrm{Cr}_{3} \mathrm{O}_{18} \cdot 32 \mathrm{H}_{2} \mathrm{O}(\mathrm{CrEt})$.

The newly formed CrEt crystals, can growths on the surface of cement particles forming a diffusion barrier which explains the longer setting times of cements with chromium waste.

The increase of chromium waste content in cement matrices decreases the compressive strengths values. This could be due to the formation of new hydrates (with chromium content), especially at the surface of cement grains, hindering their hydration. Moreover, the substitution of cement (the "dilution effect") with a high amount of chromium rich waste (up to $37 \%$ ) could contribute to the decrease of compressive strength.

Acknowledgements:The SEM analyses were possible due to EU-funding project POSCCE-A2-O2.2.1-2013-1/Prioritary Axe 2, Project No. 638/12.03.2014, ID 1970, SMIS-CSNR code 48652.

\section{References}

1.MODAK, P., Towards a Green Economy: Pathways to Sustainable Development and Poverty Eradication, www.unep.org/greeneconomy UNEP, 2011.p. 1-631

2.OPROIU, C., VOICU, G., NICOARA, A.I., BADANOIU, A.I., Rev. Chim. 69, no. 4, 2018, p. 860-863.

3.STĂNESCU, G., BĂDĂNOIU, A., NICOARĂ, A.-I., VOICU, G. Rev. Chim., 70, no. 3, 2019, p. 828-834.

4.GHEORGHE, M.; RADU, L.; NASTAC, D.; SACA, N. Rev. Rom. Mat. 43, 2013, p. 81-89.

5.ROHAN, M. Rev. Rom. Mat. 46, 2016, p. 253-258.

6.MONCEA, A. M.; GEORGESCU, M.; BADANOIU, A.; MATEI, E. Rev. Rom. Mat. 42, 2012, p. 152-163.

7.LEISINGER, S. M.; BHATNAGAR, A.; LOTHENBACH, B.; JOHNSON, C. A. Appl. Geochem. 48, 2014, p. $132-140$.

8.ZHOU, X.; ZHOU, M.; WU, X.; WAN, S.; GEN, J.; HOU, H. Appl. Geochem 80, 2017, p. 49-57.

9.SAEED, K. A.; KASSIM, K. A.; EISAZADEH, A. Electron. J. Geotech. Eng. 17S, 2012, p. 2555-2562.

10.BOUZEROURA, M.; BOUAFIA, Y.; MOUSSACEB, K.; DJENADI, R. Rev. Rom. Mat. 47, 2017, p. 406-414.

11.CHEN, Q. Y.; TYRER, M.; HILLS, C. D.; YANG, X. M.; CAREY, P. Waste Manag. 29 (1), 2009, p. 390-403.

12.CHERIF, B.; KARIM, S.; KARIM, M.; ABDELKADER, H.; CHAHINEZ, A. Rev. Rom. Mat. 48, 2018, p. $260-267$.

13.GINEYS, N.; AOUAD, G.; DAMIDOT, D. Cem. Concr. Compos. 32 (8), 2010, p. 563-570.

14.LASHERAS-ZUBIATE, M.; NAVARRO-BLASCO, I.; FERNÁNDEZ, J. M.; ÁLVAREZ, J. I. J. Hazard. Mater. 233,2012 , p. 7-17.

15.HEKAL, E. E.; KISHAR, E. A.; MOHAMED, M. R.; MAHMOUD, M. K.; MOHAMED, B. A. HBRC J. 8 (3), 2012 , p. $153-158$.

16.CHRYSOCHOOU, M.; DERMATAS, D. J. Hazard. Mater. 136 (1), 2006, p. $20-33$.

17.GIERGICZNY, Z.; KRÓL, A. J. Hazard. Mater. 160 (2-3), 2008, p. 247-255.

18.ZHANG, M.; YANG, C.; ZHAO, M.; YANG, K.; SHEN, R.; ZHENG, Y. J. Hazard. Mater. 321, 2017, p. $281-289$.

19.ZHANG, M.; YANG, C.; ZHAO, M.; YU, L.; YANG, K.; SHEN, R.; ZHU, X. J. Hazard. Mater. 324, 2018, p. $242-251$.

20.VOLLPRACHT, A.; BRAMESHUBER, W. Cem. Concr. Res. 79, 2016, p. 76-92.

21.OPROIU, C.; PÂRVAN, M.; VOICU, G.; BADANOIU, A.-I. Rev. Rom. Mat. 48, 2018, p. 458-466.

22.WAGH, A. S. Chemically bonded phosphate ceramics - Twenty-first century materials with diverse applications; Elsevier Science Ltd.: UK, 2004.

23.***SR EN 196-6. Part 6. Determination of fineness, 2018.

24.***SR EN 196-1. Part 3. Methods of testing cement - Part 3: Determination of setting time and soundness, 2017.

25.***SR EN 196-1. Part 1. Methods of testing cement - Part 1: Determination of strength, 2016.

26.***SR EN 12457-2. Characterization of waste. Leaching. compliance test for leaching granular waste materials and sludges., 2002.

27.FERNÁNDEZ-CARRASCO, L.; TORRENS-MARTÍN, D.; MORALES, L. M.; MARTÍNEZ-RAMÍREZ, S. In Infrared Spectroscopy - 
Materials Science, Engineering and Technology; InTech, 2012.

28.ŻAK, R.; DEJA, J. Spectrochim. Acta Part A Mol. Biomol. Spectrosc. 134, 2015, p. 614-620.

29.PERKINS, R. B.; PALMER, C. D. Appl. Geochemistry 15 (8), 2000, p. 1203-1218.

30.TAYLOR, H. F. W. Cement Chemistry; Thomas Telford Limited (Ed), 1997.

31.TAYLOR, H. F. W. Cem. Concr. Res. 29 (8), 1999, p. 1173-1179.

32.CAMPBELL, D. H. Microscopical examination and interpretation of Portland cement and clinker, 2; Portland Cement Association: Skokie IL, 1999.

33.***Ministry of Environment and Water Management. Romania the Ministerial Order no 95/2005 (in romanian) - Order for establishing the acceptance criteria and preliminary waste acceptance procedures at storage and the national list of waste accepted in each cl; 2005.

Manuscript received: 28.06 .2019 